\title{
Governance Mode in Reverse Logistics: A Research Framework
}

\author{
Qing $\mathrm{Lu}^{\#}$, Mark Goh* and Robert De Souza \\ The Logistics Institute - Asia Pacific \\ National University of Singapore \\ Singapore
}

\section{Introduction}

Traditional Supply Chain Management (SCM) is concerned with the flow of raw materials and finished goods (Prahinski \& Kocabasoglu, 2006). Today, the scope for SCM in the context of environmental sustainability has extended to include the reverse flow of unsold finished goods, parts and packaging materials from the point of consumption back to the organization or to the rework / refurbishing vendors (Rogers \& Tibben-Lembke, 2001). With the rise in environmental awareness, many companies have started to reduce waste, recycle, and refurbish their products for a more sustainable future. Governments in many countries are starting to develop clearer and stricter environmental regulations on issues such as the disposal of chemical waste, clean production, and carbon emissions. For example, firms in Europe are expected to "take-back" the environmentally hazardous products and packaging for recycling or reuse (Kumar \& Putnam, 2008).

Today, reverse logistics has been adopted significantly by the automotive and aerospace spare parts markets as well as the electronics and computer hardware markets. The practice of reverse logistics offers several advantages to a company in terms of both tangible and intangible benefits. First, companies are able to retrieve defective equipments and parts which are either salvaged or refurbished and thus reclaim value out of the defective parts. Already, the annual value of commercial returns has exceeded US\$100 billion (Stock et al., 2002). Second, the packaging and defective materials are collected and recycled thereby generated scrap value back for the company. Companies have found more economic value in better managing the reverse supply chain (Stock et al., 2006). Third, in the eyes of the customer and society, the organization could gain a good standing and reputation of being a responsible company that takes care of hazardous wastes with effective corporate social responsibility policies. Thus, a supply chain that can differentiate the returned products early and recover timely valuable parts can yield a competitive advantage (Guide et al., 2006).

\footnotetext{
\# Correspondent author: Contacting address: 21 Heng Mui Keng Terrace, \#04-01, Singapore 119613.

* Present address: School of Management, University of South Australia, Adelaide, South Australia 5001, Australia.
} 
In the consumer electronics sector, refurbished computers are sold at cheaper prices by all the leading brands and the demand for such laptops seems to be growing. The spare parts used by the computer manufacturers to service their products on warranty or on sale, include refurbished parts. Many electronic and consumer durable manufacturing companies offer buy back or exchange offer for the old equipment in lieu of the customer purchasing new equipment. However, managing the reverse logistics process is as operations intensive and complex as the forward supply chain, demanding the same focus and can involve multiple logistics partners such as 3PLs. Companies such as IBM, HP, Dell and Xerox have established deep processes and networks of refurbishing centres aligned with spare parts distribution centres. Unlike managing good parts inventory, defective spare parts require more handling and processes at the 3PL end. It has been commonly noticed that while the process demands defective parts to be returned in good condition, both the users and retailers do not pay enough attention to handling defective parts. Statistics suggest that defective parts suffer more damage in transit and handling than good parts.

In the automotive and aerospace industries, reverse logistics is closely linked to spare parts management or service parts logistics. In the automobile industry, the profit margin of the after-sale service is much higher than that of selling new cars, particularly for cars in the low price / high volume segments (Maxton \& Wormald, 2004). While manufacturers continue to face constant downward pressure due to the higher costs of materials, lower sales, and stiffer competition, the aftermarket business is able to maintain positive growth because of the consolidation in the market which produces economies of scale, and the fact that people are holding on to cars longer and therefore demand more replacement parts. Further, with the frequent vehicle recalls in recent years, an unfortunate side effect of rapid product innovation, the volume can be even higher than the annual sale as is the case of Toyota in 2010 (Bensinger, 2010).

In the aerospace industry, the extent of outsourcing by manufacturers is as high as $80 \%$ (Harney, 2005). Similarly, over 70 percent of a product's total value is created by suppliers in the automotive industry (Leenders et al., 2002). Many spare parts are with the supplier rather than the manufacturer. The management of outsourced supplies in both quality control and chain coordination is a critical issue for both forward and reverse SCM (Youngdahl et al., 2008).

With the growing level of complexity connected to outsourcing, especially offshore outsourcing, many companies have considered and applied the option of outsourcing part of or their entire reverse supply chain to 3PLs. In the aerospace industry, many manufacturers have passed the responsibility of the maintenance, repair and overhaul to an OEM or a third party who specializes in the field. Service technologies have become so specialized that it makes sense to outsource to a specialist like Smart Signal, a company which makes systems that monitor the performance of plane engines to predict probable breakdowns (Harney, 2005). In the automotive industry, 3PLs are also heavily involved in reverse logistics such as shipping returned products. Some manufacturers also outsource the warehousing function of their spare parts to 3PLs as in the case of Embraer in Singapore (Haq, 2007). In general, 38\% manufacturers have outsourced reverse logistics according to 2009 14th Annual Third-Party Logistics Study (Langley, 2009).

Some benefits of reverse logistics outsourcing include SCM cost reduction through leveraging on the 3PL's pooled demand as well as its professional expertise and better operational or technology infrastructure for SCM functions. The focal firms can avoid huge 
capital expenditures in facilities and enjoy the benefits of flexibility afforded by the 3PLs, which release them to focus on their core competencies (Li \& Olorunniwo, 2008).

Research to date has not investigated reverse supply chain governance with theoretical rigor. A realistic and rigorous examination on reverse logistics governance is valuable for both academia and practice. What are the advantages and weaknesses of third-party governance? For a manufacturer facing a complex reverse supply chain, should the firm choose outsourcing or invest in supply chain self governance to improve chain coordination? Which aspects of reverse supply chain should be outsourced to reduce cost and which should be kept in-house? How should the firm search for such a 3PL?

This paper views reverse logistics outsourcing as a "buy" decision in SCM, similar to the ordinary outsourcing as a "buy" in the field of firm strategy. The make-or-buy problem is a fundamental issue in strategic management (Rumelt et al., 1994: 564), and various theories such as transaction cost economics (TCE) and resource-based view (RBV) can be applied. We propose a cost-value framework providing a comprehensive account to compare the benefits and costs of the make-or-buy decision in the context of reverse logistics so as to help the manufacturers evaluate the feasibility of reverse logistics outsourcing. This study contributes to the literature by providing a research framework on reverse logistics governance as well as practical suggestions for firms to improve on reverse supply chain collaboration and performance.

The rest of the chapter is organized as follows. We review the outsourcing governance literature as well as some current practices. A research framework that systematically compares the relative benefits and cost of reverse logistics outsourcing versus a selfmanaged reverse supply chain is then presented. Five sets of propositions are presented for further empirical investigation. The discussions and implications follow thereafter.

\section{Review on reverse logistics governance \& research framework}

In a typical supply chain, a focal manufacturer procures from multiple suppliers and sends its products to multiple customers. Under globalization, these suppliers and customers can be located in faraway countries, and the manufacturer needs to find effective ways to manage the flow of goods along a disintegrated and dispersed supply chain. When customers decide to return the products or seek spare parts for repair, the manufacturer normally needs to coordinate with the 3PL(s) to ship the products or spare parts, and may further work with the suppliers if the spare parts are managed in-house. When firms outsource the management of the reverse supply chain, they can choose to outsource the logistics of its supplies or end-products, or the entire reverse supply chain of certain products. For example, UPS and FedEx as 4PLs have helped their clients in the electronics industry to manage their outbound logistics as well as their reverse logistics. Some 3PLs help high-tech manufacturers like Dell manage the inventory and product returns. While this paper discusses the governance of the entire reverse supply chain, it can be applied to part of the chain governance also. The firm can manage the overall reverse chain by itself but outsource the governance of one section to a third party.

The manufacturer needs to consider three fundamental issues when selecting its reverse supply chain partners and the corresponding governance modes, namely, capability, past relationships, and uncertainty according to the management literature (e.g., Folta, 1998; Hoetker, 2005; Vivek et al., 2008). Hereafter, we focus on the impact of the industry and firm characteristics, and exclude the influence of past relationships which is relationship specific. 
Various theories have been used to explore these issues. For instance, TCE focuses on the effect of transaction characteristics such as uncertainty and asset specificity on the associated governance costs. It then asks how the make-or-buy decision or another hybrid governance form such as joint ventures magnifies or diminishes that effect (Williamson, 1981; Williamson, 1991). From another lens, RBV looks at the partners' technical capabilities and the potential synergies from combining the partners' resources such as reducing redundant resources and knowledge exchange resulting in new capabilities (Barney, 1991; Madhok, 2002). In addition, scholars have applied real option theory to technology sourcing and identified two types of uncertainty with different implications on governance costs: exogenous uncertainty, i.e., uncertainty largely unaffected by the actions of the partner such as technological uncertainty, and endogenous uncertainty, i.e., uncertainty can be decreased by action of the partner (Folta, 1998). While integration can reduce endogenous uncertainty, external equity collaboration is more effective in controlling exogenous uncertainty (Folta, 1998; Van De Vrande et al., 2009).

TCE is concerned with managing the exchange efficiently to minimize the total transaction cost and is based on the central assumption of firm opportunism (Williamson, 1991; Balakrishnan \& Koza, 1993). Exchange attributes such as information asymmetry (Balakrishnan \& Koza, 1993), asset specificity (Williamson, 1991), and performance measurement difficulty (Williamson, 1981) would influence the effectiveness of the governance mode, which ranges from a one-off contractual relationship (market), franchises, non-equity alliances, joint ventures, to full integration (hierarchy). An organization can deploy a variety of nonmarket or structural mechanisms, including bureaucratic administration to reduce the transaction cost and contain opportunism (Williamson, 1991). A zero transaction cost environment would lead to perfect market competition in which all exchanges would be executed by contracts while high transaction costs would bring in vertical integration and bureaucratic control.

RBV starts from the heterogeneity of firms and asserts that the firm-specific resource is the primary reason for superior firm performance, which is built through an ongoing learning process (Wernerfelt, 1984; Barney, 1991). Given the resource heterogeneity (resources that differ), imperfect mobility of assets (resources not easily moved between firms), ex post limits on competition, and ex ante limits on competition (limitations exist on competitive resource position and valuation), firms are able to maintain their competitive advantage in an imperfect market (Peteraf, 1993). However, firms operating in an uncertain environment are often difficult to discern which resources are critical for future success. Capability building through learning and experimentation is of paramount concern to them (Madhok, 2002; Gans \& Stern, 2003).

Real option theory highlights the exogenous uncertainty beyond the control of firms such as environmental turbulence and technological newness (Van De Vrande et al., 2009). As these uncertainties largely resolve over time, it suggests that firms keep their options open when costs are high. Hybrid governance modes such as alliances can be seen as options for the focal firm to defer the internal development or acquisition of a targeted firm (e.g., Folta, 1998; Hagedoorn \& Duysters, 2002). By deferring the full commitment, the firm can limit its exposure to any exogenous uncertainty while keeping a means to capitalize on growth opportunities and potential benefits (Folta, 1998).

There are many studies applying these theoretical lenses to the context of outsourcing, especially supplier outsourcing, and some recent literature have made attempts in incorporating the key concerns of each body of them together. TCE and RBV literature have 
been integrated in an empirical study on the sourcing decisions of notebook computer manufacturers for innovative flat-panel displays, and it is found that the relative importance of supplier capabilities, past relationships, and being an internal or external supplier, is contingent on the level of uncertainty posed by the desired innovative component (Hoetker, 2005). In a longitudinal study of off-shoring relationships, it is reported that such relationships begin with calculative trust and opportunism, which later leads to resourcebased competency building and non-economic trust. It starts from transactional to resource complementarities, and finally to a phase where trust and long-term orientation governs the process (Vivek et al., 2009).

When applying these theoretical perspectives to reverse logistics outsourcing, we use the transaction value approach to synthesize the multiple theories created (Zajac \& Olsen, 1993). In contrast to uncertainty or time used before, transaction value is more rigorous and quantitative for general use. It is based on the premise that every governance mode comes with its own cost and value, and the manufacturer should maximize the net transaction value. Pure cost minimization may not be sufficient as the co-evolution of competencies in anticipation of value gains with supply chain partners could be the key for success in some industries (Madhok, 2002). The pursuit of greater joint value from collaboration may require a governance mode that is less cost efficient if the loss of efficiency is more than offset by the value created (Zajac \& Olsen, 1993). Similarly, as both endogenous and exogenous uncertainties exist, the manufacturer faces a trade-off between the need for administrative control and the cost of commitment (Folta, 1998). While superior administrative control could minimize opportunistic cost, the associated benefits may be offset by the opportunity cost of committing aggressively to certain reverse logistics technology which may lose value after the change in government regulations. The total cost minimization should thus consider both opportunistic and opportunity cost.

We thus propose following framework to study the governance issue in reverse logistics. On the horizontal level, we examine relative benefits, relative relational cost (cost due to the conflict of interest in the supply chain), and relative external cost (cost due to external uncertainties such as the cost of early commitment). On the vertical level, we examine uncertainty and capabilities, including both stand-alone capabilities and capabilities of value creation from collaboration. We envision that this framework can aid in achieving a better understanding of the preferences of companies in the governance of their reverse logistics.

Notwithstanding the industry and firm characteristics, we can derive the following general observations as bases for further theoretical development.

- When an outsourcer has significant advantage over the manufacturer in the capabilities of managing reverse logistics, the manufacturer can obtain more benefits from outsourcing.

- When there is significant value generated from collaboration with supply chain partners in reverse logistics, the manufacturer can obtain more benefits from selfgoverning the supply chain as the chain governor would be the owner of these values.

- While high uncertainty may increase conflicts of interest between the manufacturer and the supply chain partners in reverse logistics, increase the relational costs, and make self-governance the better governance mode, external uncertainty may render the commitment of the manufacturer such as facilities obsolete after the change in external environment such as the release of new government regulations. In such cases, outsourcing can reduce the costs of commitment and create more flexibility from the perspective of the manufacturer. 


\begin{tabular}{|c|c|c|c|}
\hline $\begin{array}{c}\text { Transaction } \\
\text { Characteristics }\end{array}$ & $\begin{array}{c}\text { Relative } \\
\text { capabilities of } \\
\text { outsourcer }\end{array}$ & $\begin{array}{c}\text { Capabilities of } \\
\text { value creation } \\
\text { from collaboration }\end{array}$ & Uncertainty \\
\hline Relative benefits & $\begin{array}{c}\text { More benefits of } \\
\text { outsourcing if } \\
\text { outsourcer is } \\
\text { more capable }\end{array}$ & $\begin{array}{c}\text { Self-governance } \\
\text { can retain more } \\
\text { value created }\end{array}$ & $\begin{array}{c}\text { Self-governance can reduce } \\
\text { relational costs when } \\
\text { uncertainty is high }\end{array}$ \\
\hline $\begin{array}{c}\text { Relative } \\
\text { relational costs }\end{array}$ & & & $\begin{array}{c}\text { Outsourcing can reduce external } \\
\text { costs when uncertainty is high }\end{array}$ \\
\hline $\begin{array}{c}\text { Relative external } \\
\text { costs }\end{array}$ & & & \\
\hline
\end{tabular}

Table 1. Research framework

\section{Theory \& propositions}

We now study the governance mode choice in the context of reverse logistics from the perspective of the manufacturer by taking the industry and firm characteristics into consideration. Further elaboration of above framework is necessary for a detailed understanding of particular properties of the preference for self-governance and outsourcing. These topics are discussed in detail, in the following five sub-sections.

\subsection{Sectoral differences in the preferences for self-governance and outsourcing}

The literature on the modes of organization suggests a sector-specific understanding of the association between, on the one hand, the level of technological change in the sectors of industry, and, on the other hand, the form of the organization, be it integration through full ownership or inter-firm linkages through strategic technology alliances (Hagedoorn \& Duysters, 2002; Van De Vrande et al., 2009). It is found that environments that induce or require a large degree of learning and flexibility, such as high-tech industries, will see a prevalence for alliances, whereas mergers and acquisitions (M\&As) are dominant in the low-tech sectors of industry, where learning and flexibility is less important than in hightech industries. It is easy to understand as under the conditions of rapid technological change, as is the case of the high-tech industries, learning, organizational change, and quick strategic response ask for flexible organizational forms. More flexible forms of economic organizations, such as strategic alliances, are appropriate as new knowledge expires quickly and timely learning from partners appears more appropriate than control through a formal and hierarchical organization as such. Extending the logic to the governance of reverse logistics, we can similarly expect that the outsourcing of reverse logistics is preferred in high-tech industries. From the above framework, the rationale for outsourcing in high-tech industries include both the higher benefits from a more flexible governance mode which facilitate the value creation in collaboration as well as lower external cost due to the flexibility of outsourcing. In particular, as the time value of a returned high-tech product is relatively high, a reverse supply chain that can get returned products quickly tested for either resale or remanufacture would be valuable. An efficient reverse supply chain governed by a 3PL which can recover the value of returned products significantly would have clear advantage over a self-managed supply chain. 
On the other hand, under the conditions of little technological change, as in the low-tech industries, companies demonstrate a preference for formal and well institutionalized modes of organization and control, such as M\&As, to be the most appropriate form of external appropriation of innovative capabilities. In the context of reverse logistics, a self-managed supply chain would be preferred as control over relational costs would be more important compared to the benefits from a more flexible supply chain. Hence:

Proposition 1a: For companies operating in a high-tech sector, the outsourcing of reverse supply chain governance would be relatively preferred as a mechanism for efficiency and flexibility.

Proposition 1b: For companies operating in a low-tech sector, the self-governance of a reverse supply chain would be relatively preferred as a mechanism for better control.

These propositions may explain the prevalence of the engagement of 3PLs in reverse logistics by high-tech firms. Facing high external uncertainty, passing the risky spare parts management to 3PLs would help the high-tech firms focus on their core competencies. Due to fierce competition in the market, manufacturers have to set very liberal return policies which increase the value of return products further (Rogers \& Tibben-Lembke, 2001). An efficient return and recycle process would be valuable and professional 3PLs can meet perfectly such needs.

\subsection{Profitability differences in the preferences for self-governance and outsourcing}

In a normal organizational mode choice, firms would prefer M\&As for activities in their core business as they would generate the necessary controls (Hagedoorn \& Duysters, 2002). In the context of reverse logistics, the core business factor could be translated to the profitability of the reverse supply chain compared to the overall firm profitability. A core business would be the main source of revenue and profit for a company and is thus more important to be protected from the potential loss of capabilities due to the opportunistic behaviour of partners. Here control is more important than flexibility as well as potential benefits from collaboration with external partners. Similarly, a reverse supply chain should be controlled by the manufacturer if it is the main source of profit. Leaving the management to externals would be highly risky and dangerous. Applying our framework, the relational costs of outsourcing a highly profitable supply chain would be extremely high. Self-management would be more appropriate. However, for a reverse supply chain with little profit or even losing money, it is natural for the manufacturer to pass the governance duty to external parties. Hence:

Proposition 2a: For companies whose profits are largely from reverse logistics, the self-governance of a reverse supply chain is preferred as a mechanism for better control.

Proposition 2b: For companies whose profits from reverse logistics are little compared to other sources, the outsourcing of a reverse supply chain is preferred as a mechanism for better efficiency.

These propositions may explain the significant differences in reverse logistics governance between the automotive and aerospace industries while both industries are similar in product characteristics, supply chain structure, and have high demand for spare parts management. Both products are complex and require high engineering and manufacturing capabilities, and both can easily be broken down into major modules and systems. Both supply chains have a large base of suppliers organized in several tiers (part manufacturers, system integrators to sub-assembly suppliers) who supply to relatively few manufacturers. Both product lives are relatively long with strong demand for maintenance and spare parts and the service quality of reverse logistics is essential for the manufacturers (A.T. Kearney, 2003). 
While the outsourcing of reverse logistics is common in the aerospace industry (Harney, 2005), car manufacturers largely operate spare parts management by themselves. A key difference between the two industries is the profit margin of reverse logistics. Automotive manufacturers face steep competition, low growth, and a saturated mass market. The profit margin is very low, (the profit from selling new cars is typically less than 5\%). On the other hand, the spare parts market enjoys a much higher margin and is an important source of profits for manufacturers. Though the task of managing thousands of different parts across hundreds of car models is challenging, the profit motivation is strong enough for manufacturers to invest and manage the reverse supply chain themselves. On the contrary, the manufacturers of aircrafts are still enjoying high profit from the limited competition and the technological advantage of incumbents like Boeing and Airbus is not likely to lose in the near future. According to the clockspeed theory, the aerospace industry is one of the slowest industries in industrial environment change (Fine, 1998). Hence, it is logical for these manufacturers to pass the spare parts management to capable 3PLs.

\subsection{Knowledge \& service capabilities in the preferences for self-governance and outsourcing}

The knowledge needed for the management of reverse logistics affects the choice of governance mode significantly. It affects both the benefits and costs. On the benefits side, a manufacturer with sufficient knowledge of reverse logistics would prefer to self-manage the chain to save the trouble of searching for a capable 3PL governor as well as future negotiation costs. On the costs side, the less the knowledge base of the manufacturer on reverse logistics, the longer it will take to resolve the external costs amidst much uncertainty, making a higher level of commitment less attractive. Instead, it is prudent to first build familiarity through collaboration with more experienced partners such as the 3PLs, through which the manufacturer creates an option while learning about the opportunity ahead (Folta, 1998). When the knowledge increases, direct involvement becomes more attractive. In other words, firms that are not yet familiar with reverse SCM will first have to learn from its partners before being able to accumulate the knowledge. Therefore, when the partnering firms have dissimilar knowledge bases, the need for learning and flexibility prevails over the need for administrative control (Van De Vrande et al., 2009). Moreover, the use of less integrated governance modes enables those same firms to reverse their commitments at lower sunk costs at any point in time.

Besides the knowledge issue, service capabilities are important for the governance of reverse logistics, which would affect the relative benefits in the governance mode choice. The on-site inspection and maintenance as well as the on-time provision of spare parts are often important in reverse logistics. A manufacturer who is far away from the customer would naturally prefer to find local partners to help in after-sale services and reverse SCM. It may explain the reason for Embraer, an aircraft manufacturer based in Brazil, to engage a 3PL in Singapore to serve its customers in the Asia Pacific. Hence:

Proposition 3a: For companies who are knowledgeable about reverse logistics, the self-governance of the reverse supply chain is preferred compared to companies not familiar with reverse logistics.

Proposition 3b: For companies who are more capable of serving customers effectively, the self-governance of the reverse supply chain is preferred compared to companies less capable in serving customers.

These propositions may yet be another reason for reverse logistics outsourcing in the hightech industry. Firms in high-tech industry normally specialized in developing commercially viable innovative products, and supply chain management is not their expertise. It is therefore logical for them to pass the duty of chain governance to a 3PL. 


\subsection{Pooling ability}

Reverse logistics is less standardized compared to the forward supply chain. Goods are less likely to be shipped in high volumes, and demand is more difficult to predict. Thus, the cost of managing reverse logistics is often higher than that of the forward supply chain. The pooling ability of the chain governor would be one important aspect of its capabilities and affect supply chain cost significantly. It can increase relative benefits in the transaction value analysis framework.

In the governance of a forward supply chain, Li \& Fung is a typical supply chain governor. It is a Hong Kong-based company which serves private label apparel firms in Europe and North America, and is known to operate as a "smokeless" factory by maintaining a large network of suppliers even though it does not own any factory. By using its buying power and trust developed with its supply base, Li \& Fung is able to considerably shrink the delivery cycle of time sensitive products (Fung et al., 2008). The pooling effect is important in the supply chain management of Li \& Fung, which keeps a rule of having at least 30\% but not more than $70 \%$ business from a specific supplier to ensure sufficient leverage for supplier compliance but still keep its independence (Fung et al., 2008). However, different from leveraging as power in the forward supply chain, pooling in reverse logistics is more cost centred as it could significantly lower the supply chain cost. 3PLs thus often enjoy advantage over manufacturers as they are able to consolidate shipping orders from multiple manufacturers. Hence:

Proposition 4: The stronger the pooling ability held by the third party over the manufacturer in reverse logistics, the more suitable it is for the third party to manage the reverse supply chain.

A corollary from Proposition 4 is that small manufacturers are more likely to engage 3PLs (or large firms but having a small customer base in a region) while large firms would prefer to self manage the reverse supply chain.

\subsection{Regulatory uncertainty}

In contrast to a forward supply chain where the market force is the main external factor, the hands of governmental regulation are much more visible in reverse logistics. With increasing environmental awareness, governments, particularly those in developed countries, are pressing manufacturers and distributors to reduce the production of environmentally hazardous products and packages (Kumar \& Putnam, 2008). For example, regulations on End-of-life Vehicles (ELV) Directive adopted by the European Union (EU) in 2000 have motivated manufacturers like Volvo, Saab, and BMW to redesign their cars so that their components can be dismantled more efficiently (Kumar \& Putnam, 2008).

New government regulations can change the rule of the game significantly, and manufacturers have to comply to participate in the marketplace and often need to redesign their products and packaging to meet these requirements. Both forward and reverse supply chains could be affected and reverse supply chains tend to be exposed to greater regulatory uncertainty. Thus, the manufacturer must take the potential governmental intervention into consideration in the choice between self-governance and outsourcing. According to our framework, high external costs would lead to a preference for outsourcing. Hence:

Proposition 5: The stronger the regulatory uncertainty in the industry within a region, the more suitable it is for a third party to manage the reverse supply chain.

Regions such as the EU where governments tend to be global leaders for new environmental regulation face greater regulatory uncertainty. According to Proposition 5, manufacturers in industries with significant outputs of environmentally hazardous materials should outsource their reverse logistics in such regions. Table 2 summarizes the above propositions. 


\begin{tabular}{|c|c|c|c|c|c|c|}
\hline $\begin{array}{l}\text { Propositions } \\
\text { (assumes the } \\
\text { external } \\
\text { governor is } \\
\text { capable) }\end{array}$ & $\begin{array}{l}\text { Whether } \\
\text { the firm is } \\
\text { in high- } \\
\text { tech } \\
\text { industries }\end{array}$ & $\begin{array}{l}\text { Whether } \\
\text { reverse } \\
\text { logistics is } \\
\text { an } \\
\text { important } \\
\text { profit } \\
\text { source }\end{array}$ & $\begin{array}{l}\text { Firm's } \\
\text { knowledge } \\
\text { about reverse } \\
\text { logistics }\end{array}$ & \begin{tabular}{|l|} 
Serving \\
capabilities \\
of the focal \\
firm
\end{tabular} & $\begin{array}{l}\text { Pooling } \\
\text { capabilities } \\
\text { advantage } \\
\text { of the third } \\
\text { party }\end{array}$ & $\begin{array}{l}\text { Regulatory } \\
\text { uncertainty }\end{array}$ \\
\hline $\begin{array}{l}\text { Relative } \\
\text { benefits }\end{array}$ & $\begin{array}{l}\text { If high-tech } \\
\text { industry, } \\
\text { more value } \\
\text { from the } \\
\text { third-party } \\
\text { governance }\end{array}$ & \begin{tabular}{|l|} 
If main \\
profit \\
source, \\
more value \\
preserved \\
by self- \\
governance
\end{tabular} & $\begin{array}{l}\text { If knowledge- } \\
\text { able, more } \\
\text { value in self- } \\
\text { governance }\end{array}$ & \begin{tabular}{|l|} 
If capable, \\
more value \\
in self- \\
governance
\end{tabular} & $\begin{array}{l}\text { If } \\
\text { significant, } \\
\text { more value } \\
\text { in third- } \\
\text { party } \\
\text { governance }\end{array}$ & \\
\hline $\begin{array}{l}\text { Relative } \\
\text { relational } \\
\text { costs }\end{array}$ & & $\begin{array}{l}\text { If main } \\
\text { profit } \\
\text { source, } \\
\text { lower } \\
\text { relational } \\
\text { costs by } \\
\text { self- } \\
\text { governance }\end{array}$ & $\begin{array}{l}\text { If knowledge- } \\
\text { able, lower } \\
\text { relational } \\
\text { costs in self- } \\
\text { governance }\end{array}$ & \begin{tabular}{|l|} 
If capable, \\
lower \\
relational \\
costs in \\
self- \\
governance
\end{tabular} & & \\
\hline $\begin{array}{l}\text { Relative } \\
\text { external } \\
\text { costs }\end{array}$ & $\begin{array}{l}\text { If high-tech } \\
\text { industry, } \\
\text { lower } \\
\text { external } \\
\text { costs in } \\
\text { third-party } \\
\text { governance }\end{array}$ & & $\begin{array}{l}\text { If knowledge- } \\
\text { able, lower } \\
\text { external cost } \\
\text { in self- } \\
\text { governance }\end{array}$ & & & $\begin{array}{l}\text { If high, } \\
\text { lower } \\
\text { external } \\
\text { costs in } \\
\text { third-party } \\
\text { governance }\end{array}$ \\
\hline $\begin{array}{l}\text { Overall } \\
\text { conclusion }\end{array}$ & $\begin{array}{l}\text { If high-tech } \\
\text { industry, } \\
\text { external } \\
\text { third-party } \\
\text { preferred; } \\
\text { else, self- } \\
\text { governance } \\
\text { preferred }\end{array}$ & $\begin{array}{l}\text { If main } \\
\text { profit } \\
\text { source, self- } \\
\text { governance } \\
\text { preferred; } \\
\text { else, third } \\
\text { party } \\
\text { preferred }\end{array}$ & $\begin{array}{l}\text { If knowledge- } \\
\text { able, self- } \\
\text { governance } \\
\text { preferred; } \\
\text { else, third } \\
\text { party } \\
\text { preferred }\end{array}$ & \begin{tabular}{|l|} 
If capable, \\
self- \\
governance \\
preferred; \\
else, third \\
party \\
preferred
\end{tabular} & $\begin{array}{l}\text { If the third- } \\
\text { party has } \\
\text { pooling } \\
\text { advantage, } \\
\text { third party } \\
\text { preferred; } \\
\text { else, self- } \\
\text { governance } \\
\text { preferred }\end{array}$ & $\begin{array}{l}\text { If } \\
\text { regulatory } \\
\text { uncertainty } \\
\text { is high, } \\
\text { third-party } \\
\text { preferred; } \\
\text { else, self- } \\
\text { governance } \\
\text { preferred }\end{array}$ \\
\hline
\end{tabular}

Table 2. Summary of Propositions

\section{Concluding remarks}

This chapter proposes a framework to examine the governance modes of reverse logistics. Drawing on perspectives from multiple organizational theories, we develop a general framework on the governance mode choice considering net transaction value which reflects relative benefits, relational costs and external costs. Applying the framework to the context of reverse logistics, we have generated five sets of propositions. External third-party governance is preferred when the industry is high-tech and when reverse logistics is not a 
main profit source. When the manufacturer is knowledgeable or able to serve end-customers well, self-governance is preferred. When the third-party has significant pooling advantages over the manufacturer in reverse logistics, or when the regulatory uncertainty is high, thirdparty governance is preferred. These propositions can explain some phenomena observed in various practices, and can be further investigated empirically.

While the findings in this paper are preliminary, it suggests that the most appropriate governance mode for a reverse supply chain depends on the context of that chain. Practically, for the potential candidates of third-party governors such as 3PLs, they have to identify suitable reverse supply chains to involve and develop their capabilities accordingly. They should also manage their business carefully to consolidate sufficient pooling advantage over the manufacturers, such as having multiple customers in one industry and /or region.

A manufacturer, with a complex reverse supply chain, has to analyze the chain characteristics to know if it is possible for an external third party to govern. If the chain is suitable, it needs to further identify a capable and trustful third-party governor to do so. However, if the reverse supply chain is unsuitable for third-party governance, either the manufacturer or a strong member in the chain should assume the role of the coordinator, improve its capabilities and closely collaborate with the other chain members to improve chain efficiency.

\section{References}

A.T. Kearney, I. (2003). Restructing the global aerospace industry. Retrieved from http://www.seaonline.org/docs/Restruct_aerospa-B5929.pdf

Balakrishnan, S.\& Koza, M. P. (1993). Information asymmetry, adverse selection and jointventures. Journal of Economic Behavior and Organization, 20, 99-117.

Barney, J. B. (1991). Firm resources and sustainable competitive advantage. Journal of Management, 17(1), 99-120.

Bensinger, K. (2010). Toyota dealers to start fixing defective gas pedals. Los Angels Times.

Fine, C. (1998). Clockspeed: Winning Industry Control in the Age of Temporary Advantage. Perseus Books, Reading, MA.

Folta, T. B. (1998). Governance and uncertainty: the trade-off between administrative control and commitment. Strategic Management Journal, 19(11), 1007-1028.

Fung, V., Fung, W.\& Wind, Y. (2008). Competing in a flat world: Building enterprises for a borderless world. Wharton School Pub, Upper Saddle River, NJ.

Gans, J.\& Stern, S. (2003). The product market and the market for "ideas": commercialization strategies for technology entrepreneurs. Research Policy, 32(2), 333-350.

Guide, V. D. R. J., Souza, G. C., van Wassenhove, L. N.\& Blackburn, J. D. (2006). Time value of commercial product returns. Management Science, 52(8), 1200-1214.

Hagedoorn, J.\& Duysters, G. M. (2002). External sources of innovative capabilities: the preference for strategic alliances or mergers and acquisitions. Journal of Management Studies, 39(2), 167-188.

Haq, R. (2007). Embraer outsources Singapore logistics hub. Arabian Business.Com. Retrieved from http://www.arabianbusiness.com/10598-embraer-outsources-singaporelogistics-hub

Harney, J. (2005). Suppliers fly up the value chain for airplane manufacturers. Outsourcing Journal. Retrieved from http://www.outsourcing-journal.com/jun2005bmanufacturing.html 
Hoetker, G. (2005). How much you know versus how well I know you: Selecting a supplier for a technically innovative component. Strategic Management Journal 26, 75-96.

Kumar, S.\& Putnam, V. (2008). Cradle to cradle: Reverse logistics strategies and opportunities across three industry sectors. International Journal of Production Economics, 115(2), 305-315.

Langley, J. (2009). The State of Logistics Outsourcing: 2009 third-party logistics: Georgia Institute of Technology.

Leenders, M. R., Fearon, H. E., Flynn, A. E.\& Johnson, P. F. (2002). Purchasing and Supply Management. McGraw-Hill, New York.

Li, X.\& Olorunniwo, F. (2008). An exploration of reverse logistics practices in three companies. Supply Chain Management: An International Journal, 13(5), 381 - 386.

Madhok, A. (2002). Reassessing the fundamentals and beyond: Ronald Coase, the transaction cost and resource-based theories of the firm and the institutional structure of production. Strategic Management Journal, 23, 535-550.

Maxton, G.\& Wormald, J. (2004). Time for a Model Change: Re-engineering the Global Automotive Industry. Cambridge University Press, Cambridge, UK.

Peteraf, M. A. (1993). The cornerstones of competitive advantage: A resource-based view. Strategic Management Journal, 14(3), 179-191.

Prahinski, C.\& Kocabasoglu, C. (2006). Empirical research opportunities in reverse supply chains. Omega, 34(6), 519-532.

Rogers, D. S.\& Tibben-Lembke, R. S. (2001). An examination of reverse logistics practices. Journal of Business Logistics, 22(2), 129-148.

Rumelt, R., Schendel, D.\& Teece, D. (Eds.). (1994). Fundamental issues in strategy. Boston, MA: Harvard Business School Press.

Stock, J., Speh, T.\& Shear, H. (2002). Many happy (product) returns. Harvard Business Review, 80(7), 16-17.

Stock, J., Speh, T.\& Shear, H. (2006). Managing product returns for competitive advantage. MIT Sloan Management Review, 48(1), 57-62.

van de Vrande, V., Vanhaverbeke, W.\& Duysters, G. (2009). External technology sourcing: The effect of uncertainty on governance mode choice. Journal of Business Venturing, $24,62-80$.

Vivek, S. D., Banwet, D.\& Shankar, R. (2008). Analysis of interactions among core, transaction and relationship-specific investments: The case of offshoring. Journal of Operations Management, 26(2), 180-197.

Vivek, S. D., Richey, G. J.\& Dalela, V. (2009). A longitudinal examination of partnership governance in offshoring: A moving target. Journal of World Business, 44(1), 16-30.

Wernerfelt, B. (1984). A resource-based view of the firm. Strategic Management Journal, 5(2), 171-180.

Williamson, O. E. (1981). The economics of organization: The transaction-cost approach. American Journal of Sociology, 87, 548-577.

Williamson, O. E. (1991). Comparative economic organization: The analysis of discrete structural alternatives. Administrative Science Quarterly, 36(2), 269-296.

Youngdahl, W., Ramaswamy, K.\& Verma, R. (2008). Exploring new research frontiers in offshoring knowledge and service processes. Journal of Operations Management, 26(2), 135-140.

Zajac, E.\& Olsen, C. (1993). From transaction cost to transaction value analysis: Implications for the study of interorganizational strategies. Journal of Management Studies, 30(1), 131-145. 


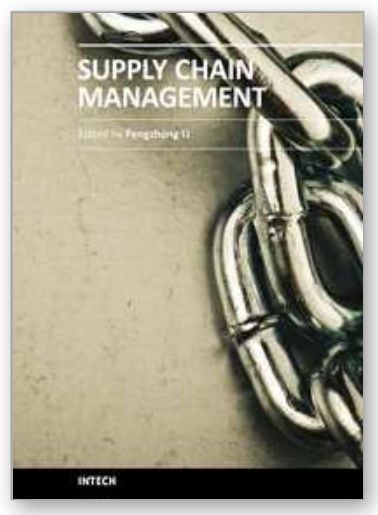

\section{Supply Chain Management}

Edited by Dr. pengzhong Li

ISBN 978-953-307-184-8

Hard cover, 590 pages

Publisher InTech

Published online 26, April, 2011

Published in print edition April, 2011

The purpose of supply chain management is to make production system manage production process, improve customer satisfaction and reduce total work cost. With indubitable significance, supply chain management attracts extensive attention from businesses and academic scholars. Many important research findings and results had been achieved. Research work of supply chain management involves all activities and processes including planning, coordination, operation, control and optimization of the whole supply chain system. This book presents a collection of recent contributions of new methods and innovative ideas from the worldwide researchers. It is aimed at providing a helpful reference of new ideas, original results and practical experiences regarding this highly up-to-date field for researchers, scientists, engineers and students interested in supply chain management.

\section{How to reference}

In order to correctly reference this scholarly work, feel free to copy and paste the following:

Qing Lu, Mark Goh and Robert De Souza (2011). Governance Mode in Reverse Logistics: A Research Framework, Supply Chain Management, Dr. pengzhong Li (Ed.), ISBN: 978-953-307-184-8, InTech, Available from: http://www.intechopen.com/books/supply-chain-management/governance-mode-in-reverse-logistics-aresearch-framework

\section{INTECH}

open science | open minds

\author{
InTech Europe \\ University Campus STeP Ri \\ Slavka Krautzeka 83/A \\ 51000 Rijeka, Croatia \\ Phone: +385 (51) 770447 \\ Fax: +385 (51) 686166 \\ www.intechopen.com
}

\author{
InTech China \\ Unit 405, Office Block, Hotel Equatorial Shanghai \\ No.65, Yan An Road (West), Shanghai, 200040, China \\ 中国上海市延安西路65号上海国际贵都大饭店办公楼 405 单元 \\ Phone: +86-21-62489820 \\ Fax: +86-21-62489821
}


(C) 2011 The Author(s). Licensee IntechOpen. This chapter is distributed under the terms of the Creative Commons Attribution-NonCommercialShareAlike-3.0 License, which permits use, distribution and reproduction for non-commercial purposes, provided the original is properly cited and derivative works building on this content are distributed under the same license. 